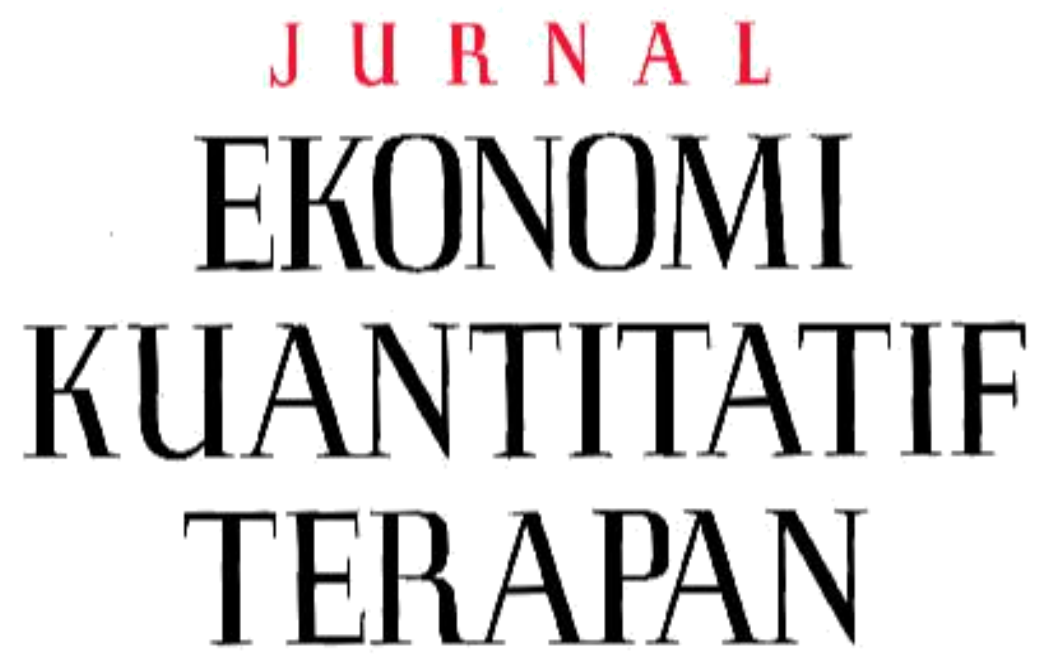

Kebijakan Fiskal Dalam Trend [embangunan Ekonomi Jangka Panjang di Indonesia I Komang Gde Bendesa, Ni Putu Wiwin Setyari

Dampak Pengeluaran Wisatawan Mancanegara terhadap Perekonomian Indonesia: Andhiny Adyaharjanti, Djoni Hartono

Analisis Efek Penularan Melalui Pendekatan Risiko Sistemik dan Keterkaitan Keuangan: Studi Pada DualBanking System di Indonesia Setyo Tri Wahyudi, Rihana Sofie Nabella, Ghozali Maski

Elastisitas Permintaan Gandum dan Produk Turunan Gandum di Indonesia Saaroh Nisrina Saajidah, I Wayan Sukadana

Peran Riset dan Pengembangan (R\&D) Akademis Terhadap Pertumbuhan Ekonomi Abdul Khaliq

Apakah Pendidikan Tinggi Meningkatkan Kemungkinan untuk Bekerja di Sektor Formal?: Bukti dari Data SAKERNAS Rizky Maulana

Pekerja Anak di Indonesia : Peran Penawaran dan Permintaan Keternagakerjaan Resa Surya Utama, Dwini Handayani

Faktor Eksternal dan Internal Penentu Kekuasaan Perempuan Bali Dalam Pengambilan Keputusan Rumah Tangga di Provinsi Bali Putu Ayu Pramitha Purwanti

Willingness To Pay (WTP) Iuran Pemberdayaan LPD kepada Lembaga Pemberdayaan LPD (LPLPD) di Kecamatan Bangli dan Kecamatan Susut Kabupaten Bangli (Pendekatan Ekonomi Kelembagaan) I Nengah Kartika, I Made Jember

Pola Perilaku Komuter dan Stres: Bukti dari Jabodetabek Gema Akbar Riadi, Muhammad Halley Yudhistira 


\section{J U R N A L \\ EKONOMI \\ KUANTITATIF \\ TERAPAN}

VOLUME $13 \quad$ NO.1 FEBRUARI 2020

\section{SUSUNAN REDAKSI}

EDITOR

I Wayan Sukadana

Ni Putu Wiwin Setyari

Anak Agung Ketut Ayuningsasi

DEWAN EDITOR

I Komang Gde Bendesa

Anak Agung Istri Ngurah Marhaeni

Luh Gede Meydianawathi

Ni Made Tisnawati

MITRA BESTARI

Adrianus Amheka, Politeknik Negeri Kupang

Made Antara, Universitas Udayana

Mohammad Arsyad, Universitas Hasanudin

Kadek Dian Sutrisna Artha, Universitas Indonesia

Djoni Hartono, Universitas Indonesia

Palupi Lindiasari, Universitas Indonesia

Devanto Shasta Pratomo, Universitas Brawijaya

Deniey Adi Purwanto, Institut Pertanian Bogor

Ni Made Sukartini, Universitas Airlangga

Setyo Tri Wahyudi, Universitas Brawijaya

Muhammad Halley Yudhistira, Universitas Indonesia

ADMINISTRASI DAN DISTRIBUSI

I Ketut Suadnyana

Ida Ayu Made Widnyani

Jurnal Ekonomi Kuantitatif Terapan diterbitkan oleh

Program Studi Ekonomi Pembangunan

Fakultas Ekonomi dan Bisnis Universitas Udayana

dua kali dalam setahun bulan Februari Dan Agustus

ALAMAT

Ruang Jurnal, Gedung BJ lantai 3

Fakultas Ekonomi dan Bisnis Universitas Udayana

Jalan PB Sudirman Denpasar

Phone: +62-361-255511/ Fax: +62-361-223344

E-mail: jekt@unud.ac.id

http://ojs.unud.ac.id/index.php/jekt

ISSN : 
Jurnal Ekonomi Kuantitatif Terapan (JEKT) adalah jurnal yang menerapkan double blind review pada setiap artikel yang diterbitkan. JEKT diterbitkan oleh Program Studi Ekonomi Pembangunan Fakultas Ekonomi dan Bisnis Universitas Udayana dua kali dalam setahun yaitu bulan Februari dan Agustus. JEKT diterbitkan sebagai kelanjutan dari Jurnal Input, Jurnal Sosial dan Ekonomi. Input terbit berkala sebanyak dua kali dalam setahun, dengan Nomor ISSN 1978-7871, dan di tahun kelima, INPUT telah terbit sebanyak sembilan edisi, dengan terbitan terakhirnya adalah Volume V, Nomor 1 Februari 2012. Pembaharuan INPUT menjadi JEKT tercetus pada pertemuan antara tim redaksi jurnal jurusan bersama pimpinan kampus, awal Maret 2012. Setelah melakukan beberapa evaluasi dan dengan merujuk kepada Peraturan Direktur Jenderal Pendidikan Tinggi Kementrian Pendidikan Nasional Republik Insonesia Nomor 49/dikti/kep/2011 tentang Pedoman Akreditasi Terbitan Berkala Ilmiah, maka terbitlah jurnal jurusan : Jurnal Ekonomi Kuantitatif Terapan dimulai dari Volume V, Nomor 2 Agustus 2012.

Jurnal Ekonomi Kuantitatif Terapan (JEKT) beralamat di Ruang Jurnal, Gedung Program Ekstensi Lantai 1, Fakultas Ekonomi dan Bisnis Universitas Udayana. Jalan PB Sudirman Denpasar, Phone: +62-361-255511/Fax: +62-361-223344. Proses registrasi dan submit artikel dapat dilakukan melalui http://ojs. unud.ac.id/index.php/jekt. Untuk bantuan teknis, penulis dapat menghubungi, email: jekt@unud.ac.id, SMS dan WA : +6281338449077.

Berdasarkan Surat Keputusan Direktur Jenderal Penguatan Riset dan Pengembangan Kementerian Riset, Teknologi, dan Pendidikan Tinggi Nomor 36a/E/KPT/2016 tanggal 23 Mei 2016, JEKT dinyatakan telah terakreditasi B oleh Dikti. Selain terakreditasi oleh Dikti, JEKT juga telah terindeks pada Google Scholar, IPI, dan DOAJ. 


\section{J U R N A L \\ EKONOMI \\ KUANTITATIF \\ TERAPAN}

\section{VOLUME 13 NO.1 FEBRUARI2020}

\section{PENGANTAR REDAKSI}

Pembaca yang terhormat,

Sampai dengan edisi ini terbit, jika pembaca menelusuri deretan jurnal-jurnal yang terdaftar di Sinta dengan kata kunci penelusuran "kuantitatif", maka yang akan muncul adalah Jurnal Ekonomi Kuantitatif (JEKT). Dengan menjadi satu-satunya jurnal dengan fokus kuantitatif, maka JEKT dituntut untuk menampilkan terbitan dengan menggunakan pendekatan kuantitatif. Kalangan peneliti ekonomi, pembangunan dan ilmu sosial lainnya di Indonesia tentunya sudah tidak asing lagi dengan penerapan metode kuantitatif dalam melakukan analisis, khususnya analisis empiris. Terlepas dari semua itu, diatas segala kemutakhiran metode kuantitatif yang digunakan, "ceritera" yang mampu menarik pembaca dan tentunya para pembuat kebijakan untuk berpastisipasi aktif dalam membaca dan menulis di JEKT adalah yang utama. Rangkaian "ceritera" yang baik dan metode kuantitatif yang sesuai tidak akan bermakna jika data yang digunakan tidak transparan dan tidak valid.

Slogan menarik mengenai data digunakan oleh BPS, "Data Mencerdaskan Bangsa", JEKT berkomitmen untuk berperan aktif dalam mewujudkan slogan tersebut menjadi kenyataan. Meskipun tidak selalu data yang digunakan artikel yang dipublikasi oleh JEKT menggunakan data BPS sebagai "menu" utama dalam analisisnya, data BPS pasti hampir selelu menjadi rujukan dalam setipa artikel dalam terbitan JEKT. Pentingnya satu pemahaman dan satu sumber dalam data memegang peran penting dalam analisis dan diskusi yang akan melahirkan implikasi kebijakan yang lebih tepat sasaran. Dalam edisi kali ini, JEKT kembali menerbitkan 10 artikel dengan sumber dan jenis data serta metodologi yang beragam.

Sumber data yang digunakan oleh penulis dalam edisi ini cukup bervariasi mulai sumber data sekunder sampai data primer. Artikel dengan sumber data sekunder sendiri juga memiliki variasi jenis data yang beragam mulai dari data mikro antara lain dari sumber BPS seperti Sakernas, seperti yang digunakan oleh Maulana untuk menjelaskan bagaimana pendidikan menentukan status pekerjaan pekerja dan Susenas serta Podes seperti yang digunakan oleh Utama dalam menjelaskan keberadaan pekerja anak di Indonesia. Sumber data mikro lain, yaitu IFLS digunakan oleh Saajadah dan Sukadana dalam mengungkapkan elastisitas permintaan gandum dan produk turunannya. Data sumber sekunder mengenai keuangan juga ditampilkan dalam edisi kali ini, Wahyudi, et.al, menjelaskan perilaku sistemik dalam industri perbankan dengan menggunakan berbagai data keuangan yang bersumber dari berbagai lembaga keuangan di Indonesia seperti OJK, BI dan sumber online Yahoo finance. 
Tidak hanya analisis mikro, edisi kali ini juga menampilkan berbagai analisis makro dengan menggunakan data sumber sekunder. Hartono, menjelaskan efek pengeluaran wisatawan dengan menggunakan data Input-output. Analisis dengan data agregate ditampilkan oleh Bendesa dan Setyari dalam menjelaskan tren pembangunan jangka panjang di Indonesia. Data publikasi BPS lainnya digunakan oleh Riyadi dan Yudhistira dalam menganalisis perilaku komuter di Jabodetabek. Artikel dengan sumber data primer juga diterbitkan dalam edisi kali ini. Purwanti dan Kartika adalah dua diantaranya, kedua penulis ini menggunakan data primer untuk menganalisis ekonomi lokal di Bali. Purwanti, menjelaskan bagaimana peran perempuan Bali dalam pengambilan keputusan rumah tangga, sedangkan Kartika menganalisis willingness to pay masyarakat lokal setempat pada lembaga keuangan lokal Bali, LPD.

Akhir kata, redaksi menyimpulkan bahwa artikel-artikel yang diterbitkan oleh JEKT mulai mengalami pergeseran sejak kemunculannya pertama kali lebih dari 10 tahun silam, utamanya dari sisi data yang digunakan. Semakin banyak artikel-artikel yang menampilkan analisis dengan menggunakan data mikro baik dari sumber sekunder maupun primer. Meskipun demikian JEKT tetap membuka diri untuk artikel-artikel dengan penggunaan data agregate. Kembali ke Alenia pembuka di atas, yang terpenting bagi JEKT dalam terbitannya adalah "ceritera" yang menarik, metode kuantitatif yang sesuai dan data yang valid. 


\title{
PEKERJA ANAK DI INDONESIA : PERAN PENAWARAN DAN PERMINTAAN KETENAGAKERJAAN
}

\author{
Resa Surya Utama \\ Dwini Handayani
}

\begin{abstract}
ABSTRAK
Anak yang bekerja akan kehilangan haknya dalam mendapatkan pendidikan optimal yang dapat merugikan pembangunan modal manusianya. Sesuai dengan teori pasar tenaga kerja, penyebab keberadaan pekerja anak dapat dilihat dari sisi penawaran dan permintaan. Penelitian ini menggabungkan data Susenas 2018 dan Podes 2018 yang dianalisis menggunakan metode regresi logistik untuk melihat pengaruh sisi permintaan dan penawaran terhadap keberadaan pekerja anak. Hasil penelitian ini menunjukkan bahwa keberadaan Industri Mikro Kecil (IMK) dan status kemiskinan berpengaruh dalam partisipasi anak dalam bekerja. Selain itu, pendidikan dan pekerjaan kepala rumah tangga (KRT) juga berperan dalam meningkatkan peluang seorang anak untuk bekerja. Program bantuan sosial perlu diberikan secara tepat untuk membantu mengentaskan permasalahan pekerja anak di Indonesia.
\end{abstract}

Kata kunci: pekerja anak, kemiskinan, permintaan tenaga kerja

\begin{abstract}
ABTRACT
This studyempirically examinesthe role of research and development (RED) in the universities on Children in employment will potentially lose their chances on education and threaten their human capital development. Labour market theory posited that their existence is in accordance to supply and demand of workforce. This study is making use of logistic regression on Susenas and Podes 2018 to examine the theory presumption. The results suggest that Micro Small Industry (IMK) presence and poverty status are playing roles in children's employment. In addition, head of household's characteristics, such as their level of education and work status, also contribute significantly. Establishing social assistance programs is paramount in solving child labour issues in Indonesia.
\end{abstract}

Keywords: child labor, poverty, labor demand

\section{PENDAHULUAN}

Peningkatan aktivitas globalisasi industri merupakan dua mata pisau dalam perkembangan pekerja anak di dunia (E. V. Edmonds and Pavcnik, 2005). Seiring dengan perkembangan era globalisasi industri, permintaan yang tinggi akan tenaga kerja menyebabkan perluasan kesempatan terhadap anak

untuk mendapatkan pendapatan yang pada akhirnya akan meningkatkan jumlah pekerja anak. Di sisi lain, globalisasi industri dapat meningkatkan pendapatan, sehingga rumah tangga tidak perlu memperkerjakan anaknya untuk menambah penghasilan (E. V Edmonds and Pavcnik, 2005; E. V. Edmonds and Pavcnik, 2005). 
Keberadaan pekerja anak akan menimbulkan hambatan dalam pembangunan sumber daya manusia (Becker, 1962, 1965; Hsin, 2007; Handono, 2009). Anak yang bekerja akan kehilangan haknya dalam mendapatkan pendidikan optimal yang dapat merugikan masa depannya dan berpotensi mengalami gangguan kesehatan di masa yang akan datang (Beegle, Dehejia and Gatti, 2009), serta rentan mengalami masalah psikologi dan sosial (Beegle et al., 2008; Wolff, 2008; Beegle, Dehejia and Gatti, 2009; Emerson and Souza, 2011).

Jumlah pekerja anak di dunia tahun 2016 mencapai 152 juta anak (ILO, 2017). Jumlah tersebut turun dibandingkan tahun 2012 yang mencapai 162 juta anak. Penurunan jumlah pekerja anak tersebut menunjukkan komitmen yang tinggi dari dunia internasional dalam menyelesaikan permasalahan pekerja anak. Namun, trend penurunannya semakin melambat dibandingkan periode sebelumnya. Ditambah lagi oleh dugaan bahwa jumlah pekerja anak yang ter data masih underestimate akibat keterbatasan sistem pengumpulan data pekerja anak di sebagian besar negara (Gibbons, Huebler and Loaiza, 2005).

Keberadaan pekerja anak di Indonesia perlu mendapat perhatian karena Indonesia menargetkan bebas pekerja anak pada tahun 2022. Berdasarkan hasil Survei Pekerja Anak tahun 2009, terdapat 6,90 persen $(4,1$ juta) anak usia 5-17 tahun yang termasuk dalam kategori anak yang bekerja (BPS, 2010).

Dalam merespons permasalahan pekerja anak, negara Indonesia telah meratifikasi konvensi Perserikatan Bangsa-Bangsa (PBB) tentang Hak-hak Anak tahun 1990 melalui Keputusan
Presiden (Kepres) No.36/0 tanggal 25 Agustus 1990. Secara hukum, Indonesia berkewajiban melindungi dan memenuhi hak-hak anak, baik hak sipil dan politik, sosial, budaya, dan ekonomi. Selain itu, Indonesia juga telah meratifikasi Konvensi ILO No. 138 melalui UU No. 20 tahun 1999 yang menetapkan bahwa usia 15 tahun adalah batasan usia minimum untuk bekerja. Beberapa peraturan perundangundangan lainnya muncul sebagai bentuk komitmen pemerintah terhadap penyelesaian permasalahan pekerja anak, di antaranya adalah UU No. 35 Tahun 2014 tentang Perubahan Atas UU No. 23 tahun 2002 tentang Perlindungan Anak dan UU No. 13 tahun 2003 tentang Ketenagakerjaan.

Pekerja anak disebabkan oleh dua faktor, yaitu faktor penarik dan pendorong. Salah satu faktor penarik yang paling kuat adalah rasionalitas perusahaan atau pemberi kerja untuk mendapatkan pekerja yang bisa dibayar dengan upah yang rendah (Levison et al., 1994; Ringdal, 2011). Sedangkan faktor pendorong yang paling kuat adalah kurangnya pendapatan rumah tangga atau kemiskinan (Verner and Blunch, 1999; Edmonds, 2006; Basu, Das and Dutta, 2010).

Di Indonesia, beragam peraturan perundang-undangan telah membatasi usia minimum untuk bekerja. Secara umum, peraturan tersebut cukup andal dalam mengendalikan perusahaan untuk tidak merekrut anak sebagai pekerja. Namun, peraturan tersebut hanya menjangkau usaha formal yang identik dengan pengawasan dari pemerintah. Sementara itu, usaha mikro dan kecil yang identik dengan sektor informal karena dikelola secara sederhana dan sebagian besar tidak berbadan hukum (BPS, 2019) tidak dapat 
dijangkau sepenuhnya oleh pengawasan pemerintah, terutama dalam hal keterlibatan anak-anak dalam proses produksinya.

Berdasarkan hasil Sensus Ekonomi (SE) tahun 2016, usaha mikro kecil (UMK) mendominasi entitas usaha, yaitu mencapai 98, 68 persen (26 juta usaha) dari seluruh entitas usaha non pertanian di Indonesia (BPS, 2019). Jumlah tersebut membuat UMK menjadi motor penggerak ekonomi masyarakat. Namun, di sisi lain, keberadaan UMK memberikan kesempatan kepada anakanak untuk lebih memilih bekerja dibandingkan bersekolah, terlebih jika UMK terletak pada lokasi yang dekat dari rumah anak sehingga mudah untuk dijangkau (Duryea and ArendsKuenning, 2003)

Di Indonesia, beberapa penelitian terkait pekerja anak sudah pernah diteliti di antaranya oleh Yeni (2016) yang melihat tentang masalah pekerja anak di Indonesia dengan menggunakan data Survei Sosial Ekonomi Nasional (Susenas) 2013 menemukan bahwa terdapat hubungan yang signifikan antara kondisi ekonomi rumah tangga terhadap peluang partisipasi anak bekerja. Selain itu, penelitian sejenis juga pernah dilakukan oleh Fitriansyah (2009) yang menemukan hubungan antara pendidikan kepala rumah tangga, jenis kelamin kepala rumah tangga, pekerjaan kepala rumah tangga, dan status sosial rumah tangga dengan peluang munculnya pekerja anak.

Berdasarkan beberapa penelitian terkait pekerja anak yang pernah dilakukan, belum ditemukan adanya penelitian yang memasukkan faktor penarik dari sisi permintaan sebagai salah satu faktor penting yang dapat menjelaskan munculnya pekerja anak. Sementara itu, keberadaan IMK sebagai salah satu faktor penarik di pasar kerja membuka peluang kepada penduduk untuk bekerja, termasuk kepada anakanak untuk bekerja akibat desakan ekonomi rumah tangganya.

Penelitian ini bertujuan untuk melihat pengaruh keberadaan IMK dan status kemiskinan terhadap peluang seorang anak untuk berpartisipasi dalam bekerja. Selain itu akan ditampilkan pula karakteristik sosial, ekonomi dan demografi anak yang berperan dalam meningkatkan peluang seorang anak untuk bekerja.

\section{TINJUAN LITERATUR}

Terdapat dua asumsi yang dikembangkan oleh Basu dan Van (1998) dalam menjelaskan konsep pekerja anak, yaitu the luxury axiom dan the substitution axiom. Kedua konsep ini dianggap telah mewakili sisi penawaran dan permintaan pekerja anak. Dalam teori the luxury axiom, rumah tangga akan menjadikan anak sebagai pekerja anak jika sumber pendapatan seluruh (ART), selain pekerja anak, sangat rendah dalam tujuannya untuk memenuhi kebutuhan rumah tangga.

Sedangkan pada teori the substitution axiom, menyatakan bahwa jika ditinjau dari sisi permintaan, pekerja anak merupakan barang substitusi dan dapat digantikan oleh tenaga kerja dewasa dan sebaliknya. Interaksi antara upaya memaksimumkan utility oleh rumah tangga melalui peningkatan pendapatan dan adanya sifat substitusi pekerja dewasa oleh pekerja anak dapat menjelaskan fenomena kemunculan pekerja anak.

Beberapa penelitian di negara berkembang menunjukkan bahwa terdapat hubungan yang sangat kuat antara kondisi ekonomi rumah tangga dengan peluang anak bekerja seperti yang dilakukan oleh (Manurung, 1998); 
Ray (2000); Usman dan Nachrowi (2004). Hasil dari ketiga penelitian ini sejalan, yaitu menjelaskan bahwa rumah tangga yang memiliki pengeluaran per kapita (sebagai proxy pendapatan) yang rendah akan membutuhkan tambahan sumber pendapatan lain untuk memenuhi kebutuhan konsumsi rumah tangga. Oleh karena itu, pekerja anak sering diidentikkan dengan kondisi kurangnya pendapatan rumah tangga dalam memenuhi kebutuhan sehari-hari yang dapat tercermin melalui ukuran kemiskinan moneter (Verner and Blunch, 1999; E. V Edmonds and Pavcnik, 2005; E. V. Edmonds and Pavcnik, 2005; Edmonds, 2006).

Pekerja anak disebabkan oleh dua faktor, yaitu faktor pendorong dan penarik anak untuk bekerja (Usman and Nachrowi, 2004). Faktor pendorong dapat diartikan sebagai faktor dari sisi penawaran yang berasal dari anak dan lingkungan keluarganya, sedangkan faktor penarik dapat diartikan sebagai faktor dari sisi permintaan tenaga kerja.

Dari sisi permintaan, pekerja anak terjadi karena adanya keputusan dari perusahaan untuk memperkerjakan anak-anak dalam proses produksinya (Ringdal, 2011). Pekerja anak-anak dianggap sebagai buruh yang lebih murah, lebih produktif, lebih gesit (nimble fingers) dan mudah diatur (Levison et al., 1994).

Keberadaan anak di pasar tenaga kerja banyak ditemukan di sektor informal (Nangia, 1994; Kolk and Van Tulder, 2002) karena masih rendahnya pengawasan dan penerapan peraturan ketenagakerjaan di sektor informal (Fassa et al., 2000), khususnya tentang batasan minimal usia kerja (Kolk and Van Tulder, 2002). Sektor informal didefinisikan berdasarkan ciri yang dimilikinya (Bonnet, Vanek and Chen,
2019) seperti jumlah unit usaha yang banyak dalam skala kecil, kepemilikan oleh individu atau keluarga, teknologi yang sederhana dan padat tenaga kerja, tingkat pendidikan dan keterampilan pekerja masih rendah, dan produktivitas tenaga kerja dan upah yang relatif rendah dibandingkan sektor formal (Bappenas, 2009). Berdasarkan karakteristik tersebut, UMK di Indonesia sebagian besarnya bercirikan sektor informal (BPS, 2019). Salah satu bagian dari UMK adalah IMK, yaitu usaha yang kegiatan utamanya adalah mengubah barang mentah atau bawang setengah jadi, atau barang jadi menjadi bentuk produk yang baru baik dengan menggunakan bantuan mesin maupun bukan mesin (BPS, 2017).

Besarnya daya serap tenaga kerja di IMK membuat IMK sering menjadi alternatif oleh para pencari kerja yang belum terserap di pasar kerja formal (Darbi, Hall and Knott, 2018), menjadi 'pelarian' awal bagi penduduk yang ingin mendapatkan tambahan pendapatan (Bappenas, 2009), bahkan sebagai early career dalam pasar tenaga kerja (Charmes, 2019). Oleh karena sektor informal bersifat easy to entry, maka peluang untuk memperoleh pekerjaan di sektor ini cukup besar (Bappenas, 2009) termasuk juga pada anak-anak (Fassa et al., 2000; Dessy and Pallage, 2003).

Karakteristik individu anak seperti umur, jenis kelamin dan tempat tinggal terbukti memiliki keterkaitan dengan partisipasi anak dalam bekerja di negara Asia, khususnya Indonesia (Manurung, 1998; Usman, 2002; Biggeri, Mehrotra and Sudarshan, 2010; Iryani and Priyarsono, 2013).

Selain dari faktor individu anak, karakteristik rumah tangga tempat tinggal anak juga perlu 
dipertimbangkan dalam menganalisis permasalahan pekerja anak. Sebagian besar penelitian sepakat bahwa pekerja anak muncul dari rumah tangga yang memiliki kerentanan ekonomi. Hal ini ditandai dengan rendahnya pendidikan kepala rumah tangga (Manurung, 1998; Usman, 2002; Iryani and Priyarsono, 2013), jenis pekerjaan kepala rumah tangga (Manurung, 1998; Usman, 2002; Triningsih and Ichihashi, 2010), koresiden anak dengan ibu kandung (Brown, Deardorff and Stern, 2002), hingga tingkat partisipasi kerja ART selain anak (Handono, 2009).

\section{METODOLOGI}

Data yang digunakan dalam penelitian ini adalah data mikro hasil Survei Sosial Ekonomi Nasional (Susenas) tahun 2018. Susenas dapat memberikan informasi karakteristik sosial-ekonomi dan demografi individu. Sumber data berikutnya adalah data mikro hasil Pendataan Potensi Desa (Podes) 2018 untuk melihat jumlah industri mikro dan kecil, jumlah sentra industri, lingkungan industri kecil, perkampungan industri kecil, serta sarana dan prasarana ekonomi seperti pasar, toko/warung kelontong, dan sejenisnya yang berada di lingkungan tempat tinggal rumah tangga/individu. Lingkungan tempat tinggal dimaksud adalah setingkat desa/kelurahan. Data ini akan digunakan untuk melihat sisi potensi permintaan tenaga kerja di suatu desa/kelurahan tempat tinggal rumah tangga/individu.

Podes 2018 merupakan data berbasis kewilayahan desa/kelurahan, sedangkan Susenas 2018 adalah data berbasis rumah tangga/individu. Oleh karena itu, sebelum melakukan pengolahan lanjutan, perlu dilakukan penggabungan kedua set data tersebut yang bertujuan untuk menambahkan atribut data kewilayahan dari Podes 2018 ke dalam data Susenas 2018. Penggabungan dilakukan dengan memanfaatkan kode dan nama desa/kelurahan yang masing-masing terdapat di kedua set data tersebut.

Unit analisis dalam penelitian ini adalah individu umur 10-17 tahun dan belum menikah, yaitu sejumlah 174.147 individu anak. Hal ini sesuai dengan batasan usia anak menurut UU Nomor 35 Tahun 2014 sebagai Perubahan Atas UU Nomor 23 Tahun 2002 tentang Perlindungan Anak, UU Nomor 13 Tahun 2003 tentang Ketenagakerjaan dan UU Nomor 1 Tahun 1974 yang dapat disintesis menjadi anak adalah setiap orang yang belum berumur 18 tahun dan belum menikah.

Pada penelitian ini menggunakan peubah respons berupa peubah dummy, maka dalam penelitian ini menggunakan metode analisis regresi logistik. Model regresi logistik digunakan untuk menganalisis data apabila peubah respons merupakan peubah berskala biner dengan satu atau lebih peubah penjelas yang dapat berbentuk kuantitatif maupun kualitatif dengan menggunakan peubah dummy (Hosmer Jr, Lemeshow and Sturdivant, 2013). Peubah respons dengan skala biner dengan menggunakan dua nilai kategorik, yaitu $Y=1$ untuk kejadian 'sukses' dan $Y=0$ untuk kejadian 'gagal' (tidak masuk dalam kategori). Peubah respons ini mengikuti distribusi Bernoulli. Bentuk umum model peluang regresi logistik dengan $p$ faktor diformulasikan sebagai berikut:

$$
\pi(x)=\frac{\exp \left(\hat{\beta}_{0}+\hat{\beta}_{1} x_{1}+\cdots+\hat{\beta}_{p} x_{p}\right)}{1+\exp \left(\hat{\beta}_{0}+\hat{\beta}_{1} x_{1}+\cdots+\hat{\beta}_{p} x_{p}\right)}
$$

Dimana:

- $\pi(x)$ : Peluang terjadinya kejadian yang 'sukses' $(Y=1)$ 
- $\beta_{j}$ : Nilai parameter, $\mathrm{j}=0,1,2, \ldots$, $\mathrm{p}$

Bentuk di atas merupakan bentuk nonlinear sehingga dibutuhkan suatu transformasi untuk mengubahnya menjadi bentuk linear menggunakan transformasi $\log$ sehingga didapatkan:

$$
\begin{aligned}
\hat{g}(x) & =\ln \hat{\pi}(x)-\ln [1-\hat{\pi}(x)] \\
& =\hat{\beta}_{0}+\hat{\beta}_{1} x_{1}+\cdots+\hat{\beta}_{p} x_{p}
\end{aligned}
$$

\begin{tabular}{|c|c|c|}
\hline Variabel & Keterangan & Kategori/Kontinu \\
\hline (1) & (2) & (3) \\
\hline \multicolumn{3}{|c|}{ Variabel Respons } \\
\hline kerja & $\begin{array}{l}\text { Partisipasi } \\
\text { Kerja }\end{array}$ & $\begin{array}{ll}0 & \text { Tidak Bekerja } \\
1 & \text { Bekerja }\end{array}$ \\
\hline \multicolumn{3}{|c|}{ Variabel Penjelas } \\
\hline$i m k$ & $\begin{array}{l}\text { Jumlah IMK di } \\
\text { desa/kel }\end{array}$ & Kontin \\
\hline pov & $\begin{array}{l}\text { Status } \\
\text { Kemiskinan }\end{array}$ & $\begin{array}{ll}0 & \text { Tidak Miskin } \\
1 & \text { Miskin }\end{array}$ \\
\hline$\overline{j k}$ & Jenis Kelamin & $\begin{array}{ll}0 & \text { Perempuan } \\
1 & \text { Laki-laki }\end{array}$ \\
\hline age & Umur Anak & Kontinu (tahun) \\
\hline corMTH & $\begin{array}{l}\text { Koresidensi Ibu } \\
\text { Kandung }\end{array}$ & $\begin{array}{llr}0 & \text { Tidak } & \text { Tinggal } \\
& \text { Bersama } & \text { Ibu } \\
& \text { Kandung } & \\
1 & \text { Tinggal } & \text { Bersama } \\
& \text { Ibu Kandung }\end{array}$ \\
\hline $\begin{array}{l}\text { edKRT1 } \\
\text { edKRT2 }\end{array}$ & $\begin{array}{l}\text { Pendidikan } \\
\text { Kepala Ruta }\end{array}$ & $\begin{array}{ll}0 & \text { Maksimal } \\
& \text { SD/sederajat } \\
1 & \text { SMP/sederajat } \\
2 & \text { SMA/sederajat ke } \\
\text { atas }\end{array}$ \\
\hline IpuKRT1 & Sektor & $\begin{array}{ll}0 & \text { Tidak Bekerja }\end{array}$ \\
\hline lpuKRT2 & Pekerjaan KRT & $\begin{array}{ll}1 & \text { Pertanian } \\
2 & \text { Non Pertanian }\end{array}$ \\
\hline$\overline{w s t K R T}$ & $\begin{array}{l}\text { Status } \\
\text { Pekerjaan KRT }\end{array}$ & $\begin{array}{ll}0 & \text { Tidak Bekerja / } \\
& \text { Bekerja Formal } \\
1 & \text { Bekerja Informal }\end{array}$ \\
\hline pulau & $\begin{array}{l}\text { Pulau Tempat } \\
\text { Tinggal }\end{array}$ & $\begin{array}{ll}0 & \text { Sumatera } \\
1 & \text { Jabalnusa } \\
2 & \text { Kalimantan } \\
3 & \text { Sulawesi } \\
4 & \text { Maluku \& Papua }\end{array}$ \\
\hline
\end{tabular}

Tabel 1. Ringkasan Variabel Penelitian

Dalam metode regresi logistik pendugaan parameternya menggunakan metode Maximum Likelihood Estimator
(MLE). Selain itu, akan digunakan juga nilai odds rasio sebagai ukuran untuk mengetahui kecenderungan pengaruh observasi $x=1$ untuk mengalami kejadian 'sukses' $(\mathrm{Y}=1)$. Dengan kata lain, menyatakan bahwa kecenderungan pengaruh observasi $\mathrm{x}=1$ adalah beberapa kali lipat dibandingkan dengan observasi $\mathrm{x}=0$ untuk mengalami kejadian 'sukses' ( $\mathrm{Y}=1)$. Sedangkan untuk peubah dengan skala kontinu, koefisien $\beta$ menunjukkan perubahan dalam $\log$ odds untuk setiap perubahan satu unit peubah $\mathrm{x}$.

\section{PEMBAHASAN \\ Profil Pekerja Anak}

Berdasarkan tabel 2, terlihat bahwa 4,4 persen anak di Indonesia tahun 2018 berstatus bekerja. Partisipasi anak dalam bekerja dapat berbeda berdasarkan jenis kelamin, umur, pendidikan KRT, lapangan usaha pekerjaan KRT, status pekerjaan KRT, keberadaan ibu kandung anak di dalam rumah tangga, dan pulau tempat tinggal anak.

Partisipasi anak dalam bekerja juga dapat berbeda berdasarkan jenis kelamin. Meskipun tidak memiliki perbedaan yang cukup besar, namun terlihat bahwa proporsi anak laki-laki yang bekerja lebih besar dibandingkan anak perempuan yang bekerja, yaitu 5,6 persen pada anak laki-laki dan 3,1 persen pada anak perempuan. Hal ini sejalan dengan banyak penelitian yang menunjukkan peluang anak laki-laki untuk bekerja lebih besar dibandingkan anak perempuan (Manurung, 1998; Ray, 2000; Usman, 2002; Biggeri, Mehrotra and Sudarshan, 2010; Iryani and Priyarsono, 2013).

Kehadiran ibu kandung di rumah tangga sangat besar peranannya dalam pembentukan modal manusia anak 
melalui motivasi yang diberikan kepada anak untuk bersekolah dibandingkan ikut berpartisipasi dalam bekerja (Brown, Deardorff and Stern, 2002). Hal ini terlihat pada tabel 2 bahwa partisipasi bekerja pada kelompok anak yang tidak tinggal bersama ibu kandung lebih besar dibandingkan pada kelompok anak yang tinggal bersama ibu kandungnya.

\begin{tabular}{|c|c|c|}
\hline Karakteristik Sosial, & Particin & si Keria \\
\hline Ekonomi, \& Demografi & Tidak & Bekerja \\
\hline (1) & (2) & (3) \\
\hline Status Kemiskinan & & \\
\hline Tidak Miskin & 95.8 & 4.2 \\
\hline Miskin & 93.7 & 6.3 \\
\hline Jenis Kelamin & & \\
\hline Perempuan & 96.9 & 3.1 \\
\hline Laki-Laki & 94.4 & 5.6 \\
\hline Koresidensi Ibu Kandung & & \\
\hline Tidak Tinggal Bersama & 93.9 & 6.1 \\
\hline Tinggal Bersama & 95.9 & 4.1 \\
\hline Pendidikan KRT & & \\
\hline Tidak Tamat SMP & 93.9 & 6.1 \\
\hline Tamat SMP & 96.5 & 3.5 \\
\hline Tamat SMA ke atas & 97.6 & 2.4 \\
\hline Lapangan Usaha KRT & & \\
\hline Tidak Bekerja & 96.3 & 3.9 \\
\hline Sektor Pertanian & 93.1 & 6.9 \\
\hline Sektor Non Pertanian & 96.8 & 3.2 \\
\hline Status Pekerjaan KRT & & \\
\hline Tidak Bekerja/Formal & 97.1 & 2.9 \\
\hline Pekerja Informal & 94.2 & 5.8 \\
\hline Pulau Tempat Tinggal & & \\
\hline Sumatera & 94.6 & 5.4 \\
\hline Jabalnusa & 96.7 & 3.3 \\
\hline Kalimantan & 94.9 & 5.1 \\
\hline Sulawesi & 92.4 & 7.4 \\
\hline Maluku dan Papua & 90.8 & 9.2 \\
\hline Total & 95.6 & 4.4 \\
\hline
\end{tabular}

Kepala rumah tangga memiliki peranan penting sebagai pengambil keputusan dalam rumah tangga, termasuk dalam membaut keputusan melibatkan anak untuk bekerja (Posel, 2001; DeGraff, Levison and Robison,
2009). Oleh karena itu, perbedaan karakteristik kepala rumah dari sisi pendidikan dan pekerjaan membuat perbedaan peluang seorang anak berpartisipasi dalam bekerja.

Berdasarkan tabel 2 terlihat bahwa semakin rendah pendidikan KRT, maka proporsi anak yang bekerja akan semakin besar. Temuan ini sesuai dengan hasil penelitian Iryani \& Priyarsono ((2013), Manurung (1998), dan Usman (2002) yang menunjukkan bahwa semakin rendah pendidikan kepala rumah tangga menandakan semakin tinggi kerentanan ekonomi rumah tangga tersebut sehingga menjadi dorongan yang kuat untuk melibatkan anaknya dalam bekerja.

Jenis pekerjaan KRT dan status pekerjaan KRT juga membuat perbedaan peluang partisipasi anak dalam bekerja. Pada tabel 2 terlihat bahwa proporsi anak yang bekerja lebih besar pada kelompok rumah tangga dengan KRT yang bekerja di sektor pertanian dan bekerja secara informal. Sehingga diindikasikan bahwa kepala rumah tangga yang bekerja di sektor pertanian maupun bekerja secara informal akan menarik anaknya untuk bekerja di sektor yang sama, baik sebagai pekerja keluarga (pekerja tak dibayar) maupun sebagai pekerja penerima upah. Hasil ini didukung oleh beberapa temuan dari penelitian sebelumnya, seperti penelitian Usman (2002) dan Manurung (1998).

Partisipasi anak dalam bekerja juga berbeda berdasarkan daerah tempat tinggal. Proporsi anak yang bekerja lebih besar pada anak yang tinggal di pulau Sulawesi, Maluku, dan Papua. Hal ini terjadi karena tingkat kemiskinan daerah-daerah di ketiga pulau tersebut lebih tinggi di atas tingkat kemiskinan nasional (BPS, 2018). 
Keberadaan anak di pasar tenaga kerja banyak ditemukan di sektor informal (Nangia, 1994; Kolk and Van Tulder, 2002). Berdasarkan ciri yang dimiliki oleh sektor informal, maka IMK di Indonesia masuk ke dalam sektor informal (Fassa et al., 2000; Bappenas, 2009; BPS, 2019).

\section{Hasil Estimasi}

Penelitian ini menggunakan teknik analisis regresi logistik untuk melihat pengaruh keberadaan IMK dan status kemiskinan rumah tangga dalam meningkatkan peluang seorang anak untuk bekerja.

Hasil estimasi dilengkapi dengan hasil uji keseluruhan model (overall test), uji ketangguhan model (robustness check), uji parsial (partial test), dan nilai rasio kecenderungan (odds rasio). Variabel penjelas utama yang digunakan dalam penelitian ini ada dua, yaitu keberadaan IMK (imk) dan status kemiskinan rumah tangga (pov). Tabel 3 menyajikan hasil estimasi pada beberapa skema model yang menggunakan kelompok observasi yang berbeda yang bertujuan untuk melihat konsistensi hasil estimasi (robustness check) variabel utama.

Berdasarkan tabel 3, terlihat bahwa keberadaan IMK dan status kemiskinan memiliki pengaruh positif terhadap partisipasi anak bekerja, baik pada kelompok observasi rumah tangga berpendapatan persentil 40,60, maupun pada keseluruhan observasi. Analisis selanjutnya akan difokuskan pada model III, yaitu model yang menggunakan keseluruhan observasi.

Tabel 3 Hasil Estimasi Regresi Logistik: Pengaruh Keberadaan IMK dan Status Kemiskinan Terhadap Partisipasi Anak Bekerja

\begin{tabular}{|c|c|c|c|c|c|c|c|}
\hline \multirow[b]{2}{*}{ Variables } & \multicolumn{2}{|c|}{$\mathbf{I}$} & \multicolumn{2}{|c|}{ II } & \multicolumn{3}{|c|}{ III } \\
\hline & Coef. & SE & Coef. & SE & Coef. & SE & Odds Rasio \\
\hline$(1)$ & $(2)$ & (3) & $(4)$ & $(5)$ & $(6)$ & $(7)$ & $(8)$ \\
\hline$i m k$ & $0.074^{* * *}$ & 0.019 & $0.056^{* * *}$ & 0.016 & $0.028^{* *}$ & 0.014 & 1.028 \\
\hline pov & $0.127^{* * *}$ & 0.033 & $0.192^{* * *}$ & 0.030 & $0.221^{* * *}$ & 0.029 & 1.248 \\
\hline$j k$ & $0.693^{* * *}$ & 0.033 & $0.687^{* * *}$ & 0.027 & $0.656^{* * *}$ & 0.023 & 1.926 \\
\hline age & $0.415^{\star * *}$ & 0.008 & $0.399 * * *$ & 0.007 & $0.391^{* * *}$ & 0.006 & 1.479 \\
\hline corMTH & -0.068 & 0.043 & $-0.075^{* *}$ & 0.036 & $-0.249^{* * *}$ & 0.028 & 0.780 \\
\hline edKRT1 & $-0.415^{* * *}$ & 0.048 & $-0.451^{* * *}$ & 0.039 & $-0.419^{* * *}$ & 0.032 & 0.658 \\
\hline edKRT2 & $-0.414^{* * *}$ & 0.048 & $-0.471^{* * *}$ & 0.039 & $-0.704^{* * *}$ & 0.030 & 0.495 \\
\hline lpuKRT1 & $0.206^{* * *}$ & 0.08 & $0.221^{* * *}$ & 0.067 & $0.388^{* * *}$ & 0.056 & 1.474 \\
\hline lpuKRT2 & $-0.251^{* * *}$ & 0.078 & $-0.229^{* * *}$ & 0.065 & -0.028 & 0.054 & 0.972 \\
\hline wstKRT & $0.426^{* * *}$ & 0.046 & $0.446^{* * *}$ & 0.037 & $0.462^{* * *}$ & 0.029 & 1.588 \\
\hline \multicolumn{8}{|l|}{ pulau } \\
\hline Jabalnusa & $-0.614^{* * *}$ & 0.043 & $-0.596^{* * *}$ & 0.036 & $-0.568^{* * *}$ & 0.030 & 0.566 \\
\hline Kalimantan & $-0.311^{* * *}$ & 0.071 & $-0.289^{* * *}$ & 0.054 & $-0.192^{* * *}$ & 0.040 & 0.825 \\
\hline Sulawesi & $0.100^{* *}$ & 0.044 & $0.101^{* * *}$ & 0.037 & $0.160 * * *$ & 0.031 & 1.173 \\
\hline Maluku E Papua & $0.114^{* *}$ & 0.048 & $0.125^{* * *}$ & 0.041 & $0.270^{* * *}$ & 0.034 & 1.309 \\
\hline $\begin{array}{l}\text { Catatan: Variabel respc } \\
\text { Model I menggunakan } \\
\text { menggunakan observas } \\
\text { keseluruhan observasi } \\
\text { diinterpretasikan. Hasi } \\
10 \%, 5 \% \text {, dan } 1 \% \text {. }\end{array}$ & $\begin{array}{l}\text { g digunaka } \\
\text { rasi anak de } \\
\text { dengan pe } \\
174.147 \text { obs } \\
\text { ll test signif }\end{array}$ & $\begin{array}{l}\text { pada set } \\
\text { fan penc } \\
\text { apatan } \\
\text { Seluruh } \\
\text { an di lev }\end{array}$ & $\begin{array}{l}\text { p model ad } \\
\text { patan perse } \\
\text { ersentil } 60 \mathrm{k} \\
\text { asil regresi } 1 \\
\text { alpha } 1 \% \mathrm{p}\end{array}$ & $\begin{array}{l}\text { lah part } \\
\text { til } 40 \text { kel } \\
\text { oawah (1 } \\
\text { enghasil } \\
\text { da setia }\end{array}$ & $\begin{array}{l}\text { pasi anak } \\
\text { wah (69.66 } \\
4.491 \text { obs) } \\
\text { n intersep, } \\
\text { model. *, }\end{array}$ & $\begin{array}{l}\text { lam beke } \\
\text { obs). Mc } \\
\text { lodel III } \\
\text { amun tid } \\
* * \text { : signif }\end{array}$ & $\begin{array}{l}\text { ja (kerja). } \\
\text { lel II } \\
\text { henggunakan } \\
\text { k } \\
\text { an pada level }\end{array}$ \\
\hline
\end{tabular}


JURNAL EKONOMI KUANTITATIF TERAPAN Vol. 13 No. 1 - FEBRUARI 2020 
Keberadaan IMK di level desa/kelurahan memiliki pengaruh positif terhadap partisipasi anak dalam bekerja. Artinya, semakin banyak keberadaan IMK di desa/kelurahan, maka peluang seorang anak untuk bekerja semakin meningkat. Hasil ini sesuai dengan penelitian Nangia (1994) yang menunjukkan bahwa sektor informal seperi IMK menjadi tempat untuk menyerap pekerja anak. Nilai odds ratio pada kolom (8) dapat diartikan bahwa saat jumlah IMK di desa/kelurahan tempat tinggal anak bertambah sebanya 100 unit usaha, maka peluang anak untuk bekerja akan meningkat 1,028 kali dibandingkan dengan jumlah IMK yang lebih sedikit. Hal ini terjadi diduga karena masih rendahnya implementasi peraturan ketenagakerjaan di IMK sehingga anak-anak dapat dengan mudah terlibat dalam bekerja di IMK, baik karena dorongan diri sendiri, maupun akibat dorongan dari orang tua.

Kondisi kemiskinan merupakan pendorong utama anak untuk berpartisipasi dalam bekerja. Hal ini dapat terlihat dari hasil estimasi yang menunjukkan pengaruh positif kondisi kemiskinan terhadap partisipasi anak bekerja. Artinya, anak yang tinggal di rumah tangga miskin akan memiliki peluang yang lebih tinggi untuk bekerja dibandingkan dengan anak yang tinggal di rumah tangga tidak miskin. Nilai odds ratio, menunjukkan bahwa anak yang tinggal di rumah tangga miskin akan memiliki kecenderungan 1,248 kali lebih tinggi dibandingkan anak yang tinggal di rumah tangga tidak miskin untuk menjadi pekerja anak. Temuan ini sejalan dengan beberapa hasil penelitian sejenis, yang menemukan bahwa pekerja anak muncul akibat kurangnya pendapatan rumah tangga (Manurung, 1998; Usman and Nachrowi, 2004; E. V Edmonds and Pavcnik, 2005).

Selain pengaruh dari keberadaan IMK dan status kemiskinan, karakteristik sosial, ekonomi dan demografi tertentu juga dapat meningkatkan peluang seorang anak untuk berpartisipasi dalam bekerja. Variabel umur anak memiliki pengaruh positif terhadap partisipasi bekerja. Artinya, semakin bertambah umur anak maka peluangnya untuk berpartisipasi dalam bekerja juga semakin tinggi karena semakin bertambah umur menandakan semakin siapnya fisik seorang anak untuk bekerja. Variabel jenis kelamin juga berpengaruh terhadap partisipasi anak dalam bekerja. Anak lakilaki memiliki peluang yang lebih tinggi untuk bekerja dibandingkan anak perempuan. Temuan ini sejalan dengan beberapa penelitian sebelumnya yang membuktikan bahwa terdapat perbedaan peluang antara anak laki-laki dan perempuan untuk bekerja (Manurung, 1998; Usman, 2002; Biggeri, Mehrotra and Sudarshan, 2010; Iryani and Priyarsono, 2013).

Selain itu, keberadaan ibu kandung anak di dalam rumah tangga berpengaruh negatif terhadap partisipasi anak dalam bekerja. Artinya, anak yang tinggal bersama ibu kandung akan memiliki peluang yang lebih kecil untuk bekerja. Kondisi ini didukung oleh informasi deskriptif pada tabel 4.2 yang menunjukkan bahwa proporsi anak yang bekerja pada kelompok anak yang tinggal bersama ibu kandung lebih kecil dibandingkan pada kelompok anak yang tidak tinggal bersama ibu kandung. Hasil temuan ini dapat dijelaskan melalui tulisan Brown et al. (2002) yang mengatakan ibu dapat menjadi kontrol dalam pengambilan keputusan rumah tangga, terutama hal-hal yang berkaitan dengan anaknya.

Tingkat pendidikan KRT yang lebih tinggi memberi pengaruh negatif terhadap partisipasi anak bekerja. Artinya, semakin tinggi pendidikan KRT, maka akan mengurangi peluang seorang anak berpartisipasi dalam bekerja. Tingkat pendidikan KRT erat kaitannya dengan pekerjaannya. KRT yang berpendidikan lebih tinggi akan lebih cenderung bekerja di sektor non pertanian. Seperti yang telah disebutkan pada bagian sebelumnya bahwa proporsi anak yang bekerja di sektor non 
pertanian lebih kecil dibandingkan yang bekerja di sektor pertanian. Hal ini juga sesuai dengan variabel dummy lapangan usaha KRT pertanian yang signifikan positif dalam mempengaruhi partisipasi anak dalam bekerja. Artinya, KRT yang bekerja di sektor pertanian akan meningkatkan peluang anak dalam rumah tangga tersebut untuk bekerja.

Partisipasi anak dalam bekerja juga dapat berbeda berdasarkan pulau lokasi tempat tinggal. Anak-anak yang tinggal di pulau Sulawesi, Maluku, Papua memiliki peluang yang lebih tinggi untuk bekerja dibandingkan anak-anak yang tinggal di pulau lainnya. Hal ini terjadi karena mayoritas penduduk di ketiga wilayah tersebut bekerja di sektor pertanian. Anakanak yang tinggal di rumah tangga pertanian akan cenderung bekerja untuk membantu usaha pertanian milik rumah tangganya sebagai pekerja keluarga atau pekerja tidak dibayar untuk menambah pendapatan rumah tangga. (Basu, Das and Dutta, 2010).

\section{KESIMPULAN DAN SARAN}

Berdasarkan hasil penelitian yang telah disampaikan pada bagian sebelumnya, dapat disimpulkan beberapa hal sebagai berikut:

1. Partisipasi anak dalam bekerja dipengaruhi oleh faktor permintaan dan penawaran. Hal ini dapat dijelaskan melalui adanya pengaruh positif dari keberadaan IMK di desa/kelurahan dan status kemiskinan terhadap partisipasi anak bekerja.

2. Peluang seorang anak untuk bekerja juga akan meningkat berdasarkan karakteristik sosial, ekonomi, dan demografi tertentu seperti jenis kelamin, umur, keberadaan ibu kandung dalam rumah tangga, pendidikan KRT, lapangan usaha KRT, dan status pekerjaan KRT.

3. Perbedaan lokasi tempat tinggal (pulau) juga membuat perbedaan peluang seorang anak untuk bekerja.
Berdasarkan hasil dan kesimpulan, berikut beberapa saran yang dapat diberikan dalam merancang kebijakan pengentasan pekerja anak, yaitu:

1. Peraturan perundang-undangan ketenagakerjaan, khususnya yang terkait dengan batasan usia minimal anak boleh bekerja sebaiknya diperluas cakupan dan penerapannya hingga ke Industri Mikro Kecil (IMK) karena terbukti jumlah IMK di suatu desa/kelurahan dapat memberikan perbedaan peluang anak bekerja.

2. Pemberian bantuan kepada rumah tangga miskin dengan sasaran khusus untuk menjaga kemampuan rumah tangga dalam memenuhi kebutuhan pokoknya, sekaligus dapat mendorong anaknya untuk bersekolah sehingga dapat berhenti dari bekerja tanpa membuat rumah tangganya menjadi semakin miskin.

\section{REFERENSI}

Bappenas (2009) Kajian Evaluasi Pembangunan Sektoral. Jakarta: Kedeputian Evaluasi Kinerja Pembangunan, Badan Perencanaan Pembangunan Nasional.

Basu, K., Das, S. and Dutta, B. (2010) 'Child labor and household wealth: Theory and empirical evidence of an inverted$\mathrm{U}^{\prime}$, Journal of development economics. Elsevier, 91(1), pp. 8-14.

Basu, K. and Van, P. H. (1998) 'The economics of child labor', American economic review. JSTOR, pp. 412-427.

Becker, G. S. (1962) 'Investment in human capital: A theoretical analysis', Journal of political economy. The University of Chicago Press, 70(5, Part 2), pp. 9-49.

Becker, G. S. (1965) 'A Theory of the Allocation of Time', The economic journal. JSTOR, pp. 493-517.

Beegle, K. et al. (2008) 'The Consequences of Child Labor : Evidence from Longitudinal Data in Rural Tanzania', Policy Research Working.

Beegle, K., Dehejia, R. and Gatti, R. (2009) 
'Why should we care about child labor? The education, labor market, and health consequences of child labor', Journal of Human Resources. University of Wisconsin Press, 44(4), pp. 871-889.

Biggeri, M., Mehrotra, S. and Sudarshan, R. (2010) 'Child labour in industrial outworker households in India'.

Bonnet, F., Vanek, J. and Chen, M. (2019)

'Women and Men in the Informal Economy: A Statistical Brief'.

BPS (2010) Pekerja Anak di Indonesia 2009. Jakarta: Badan Pusat Statistik.

BPS (2017) Klasifikasi Baku Lapangan Usaha Indonesia. Jakarta: Badan Pusat Statistik.

BPS (2018) Profil Kemiskinan di Indonesia Maret 2018. Jakarta.

BPS (2019) Analisis Hasil SE2016 Lanjutan: Potensi Peningkatan Kinerja Usaha Mikro Kecil. Jakarta: Badan Pusat Statistik.

Brown, D. K., Deardorff, A. V and Stern, R. M. (2002) The determinants of child labor: theory and evidence. School of Public Policy, University of Michigan.

Charmes, J. (2019) 'Trends and Characteristics of the Informal Economy and Its Components', in Dimensions of Resilience in Developing Countries. Springer, pp. 37-92.

Darbi, W. P. K., Hall, C. M. and Knott, P. (2018) 'The informal sector: A review and agenda for management research', International Journal of Management Reviews. Wiley Online Library, 20(2), pp. 301-324.

DeGraff, D., Levison, D. and Robison, M. (2009) 'Child labor and mothers' work in Brazil', International Journal of Sociology and Social Policy. Emerald Group Publishing Limited, 29(3/4), pp. 152-163.

Dessy, S. and Pallage, S. (2003) 'Taxes, inequality and the size of the informal sector', Journal of Development Economics. Elsevier, 70(1), pp. 225-233.

Duryea, S. and Arends-Kuenning, M. (2003) 'School attendance, child labor and local labor market fluctuations in urban
Brazil', World Development. Elsevier, 31(7), pp. 1165-1178.

Edmonds, E. V. and Pavcnik, N. (2005) 'The effect of trade liberalization on child labor', Journal of International Economics. doi: 10.1016/j.jinteco.2004.04.001.

Edmonds, E. V (2006) 'Child labor and schooling responses to anticipated income in South Africa', Journal of development Economics. Elsevier, 81(2), pp. 386-414.

Edmonds, E. V and Pavcnik, N. (2005) 'Child labor in the global economy', Journal of Economic Perspectives, 19(1), pp. 199 220.

Emerson, P. M. and Souza, A. P. (2011) 'Is child labor harmful? The impact of working earlier in life on adult earnings', Economic Development and Cultural Change. University of Chicago Press Chicago, IL, 59(2), pp. 345-385.

Fassa, A. G. et al. (2000) 'Child labor and health: problems and perspectives', International Journal of Occupational and Environmental Health. Taylor \& Francis, 6(1), pp. 55-62.

Fithriansyah, I. (2009) Determinan Rumah Tangga Pekerja Anak di Indonesia. Universitas Indonesia.

Gibbons, E., Huebler, F. and Loaiza, E. (2005) 'Child labor, education, and the principle of non-discrimination', Chapter, 10, p. 214.

Handono, P. (2009) Pengaruh Faktor Sosial Ekonomi Demgorafi Rumah Tangga Terhadap Partisipasi dan Intensitas Bekerja Anak (Analisis Data Susenas Kor Tahun 2006). Universitas Indonesia.

Hosmer Jr, D. W., Lemeshow, S. and Sturdivant, R. X. (2013) Applied logistic regression. John Wiley \& Sons.

Hsin, A. (2007) 'Children's time use: Labor divisions and schooling in Indonesia', Journal of Marriage and Family. Wiley Online Library, 69(5), pp. 1297-1306.

ILO (2017) Global Estimates of Child Labour: Results and Trends 2012-2016. Geneva: International Labour Office (ILO). 
Iryani, B. S. and Priyarsono, D. S. (2013) 'Eksploitasi terhadap Anak yang Bekerja di Indonesia', Jurnal Ekonomi dan Pembangunan Indonesia, 13(2), pp. 177-195.

Kolk, A. and Van Tulder, R. (2002) 'Child labor and multinational conduct: a comparison of international business andstakeholder codes', Journal of Business Ethics. Springer, 36(3), pp. 291301.

Levison, D. et al. (1994) 'Is child labor really necessary in Indias carpet industry?', in. [Unpublished] 1994. Presented at the Annual Meeting of the Population ....

Manurung, D. (1998) Keadaan dan FaktorFaktor yang Mempengaruhi Pekerja Anak di Indonesia. Universitas Indonesia.

Nangia, P. (1994) 'Children in the Urban Informal Sector: A Tragedy of the Developing Countries in Asia', in The Asian City: Processes of Development, Characteristics and Planning. Springer, pp. 279-294.

Posel, D. R. (2001) 'Who are the heads of household, what do they do, and is the concept of headship useful? An analysis of headship in South Africa', Development Southern Africa. Taylor \& Francis, 18(5), pp. 651-670.

Ray, R. (2000) 'Analysis of child labour in Peru and Pakistan: A comparative study', Journal of population economics. Springer, 13(1), pp. 3-19.

Ringdal, C. (2011) 'Small hands should play, not work: A theoretical analysis of interventions in child labor'. The University of Bergen.

Triningsih, N. and Ichihashi, M. (2010) 'The Impact of Poverty and Educational Policy on Child Labor in Indonesia', 1DEC Hiroshima University Discussion Paper.

Usman, H. (2002) Determinan dan Eksploitasi

Pekerja Anak-Anak di Indonesia.

Universitas Indonesia.

Usman, H. and Nachrowi, D. N. (2004)

Pekerja Anak di Indonesia: Kondisi,
Determinan, dan Eksploitasi. Jakarta: PT. Gramedia Widiasarana Indonesia.

Verner, D. and Blunch, N.-H. (1999)

Revisiting the link between poverty and child labor: the Ghanaian experience. The World Bank.

Wolff, F.-C. (2008) 'Evidence on the impact of child labor on child health in Indonesia, 1993-2000', Economics \& Human Biology. Elsevier, 6(1), pp. 143-169.

Yeni, I. (2016) Pekerja Anak di Indonesia: Bekerja Atau Tidak, Pekerjaan Berupah Atau Tidak, Dan Fungsi Upah Pekerja Anak. Universitas Indonesia. 